\section{PP-361ESWL 複数回施行症例の検討}

帝京大学ちば総合医療センター泌尿器科

一色 真造, 松野 大輔, 趙 秀孔, 小島 聡子,

佐藤 直秀, 古谷 雄三

【目的】体外衝撃波結石破砕術（ESWL）は上部尿路結石症 に対する有力な治療法であるが、時に複数の治療回数を要 し、治療に難渋することがある。今回我々は ESWL 複数回 施行症例について臨床的検討を行った。【対象と方法】2003 年 1 月から 2005 年 12 月まで当院にて複数回 ESWLを施 行した 86 例を対象とした。使用機種はドルニエリソトリプ ターDである。【結果】結石の平均長径は 15.3mm（5～40 $\mathrm{mm}$ )、平均治療回数は 3.5 回（2１5 回）であった。Stone street が 25 例に発生し、TULを追加治療として 7 例に 行った。他の治療法へ移行したものが 10 例（腎摘除術 1 例、TUL2 例、切石術 2 例、他院での治療 5 例)であった。 合併症は腎孟腎炎が 4 例、尿管カテーテル抜去困難が 2 例 であった。全症例の治療 1 ケ月後の完全排石率は $58 \%$ 、有 効率は $73 \%$ であった。治療回数 4 回以上の症例、3 回以下 の症例の治療 1 力月後の完全排石率はそれぞれ $42 \% 、 67 \%$ であった。治療回数 4 回以上の症例では追加治療を必要と する症例の割合、および合併症の発生率が高かった。考察】 ESWL が 4 回以上必要となる症例は治療困難な症例が多 く、合併症に対する慎重な注意が必要である。

\section{PP-362 ESWL 後の腎被膜下血腫の検討}

みさと健和病院泌尿器科"), 大久保病院泌尿器科2), 三井 記念病院泌尿器科 ${ }^{3)}$

西古 靖1), 上谷 恭一郎 ${ }^{1)}$, 井上 滋彦1), 内田 健三 ${ }^{2)}$, 水谷 隆3), 山口 千美 ${ }^{3)}$

【目的】当院では 2001 年 9 月より ESWLを開始した。腎結 石に対する合併症の一つである腎被膜下血腫について検討 した。【対象と方法】対象は 2001 年 9 月 2006 年 8 月まで に腎結石に対して ESWLをうけた 133 例 157 結石である。 機種はMODULITH SLX-MX (Stroz 社)を用いた。治療は 原則として 1 泊入院とし、術当日入院し翋日に血算・生化 学検查、腹部レントゲン、腹部単純 CTを施行し結石の砕石 状況や腎組織への影響を確認した。結果】セッション数は 全体で 275 回、結石あたり平均 1.75 回であった。8例に腎被 膜下血腫を認めた。発症率は 1 セッションあたり $2.9 \%$ 、結 石あたり $5.1 \%$ であった。7例は無症状か軽い背部痛を訴え るのみであったが、1例は激痛のため 1 週間の入院安静を 要した。8 例中 5 例が追跡可能であり 1 月〜 1 年で血腫の消 失を確認したが、 1 例は 2 年後の腹部 CT で患側腎の萎縮 を認めた。高血圧 3 例、糖尿病 2 例、高脂血症 1 例、高尿 酸血症 1 例の内科疾患を合併していた。考察】 ESWL 後の 腎被膜下血腫の発症は $5.1 \%$ と高率であった。腎結石の治 療にあたっては衝撃波の出力を低くして行うか、可能なら ば組織障害の少ないホロミウムレーザーによる経尿道的破 砕を行うのも選択枝の一つであると考えられた。
PP-363

ESWLにおける腎被膜下血腫・腎周囲 血腫の検 討一Dornier Lithotripter U/50 (EMSE220) と HM-3 の比較検討一

\section{大和病院泌尿器科", 齋藤記念病院泌尿器科2", 三芳厚生 病院泌尿器科 ${ }^{3)}$}

谷口 淳 ${ }^{11}$, 山本 隆次 ${ }^{1}$, 針生 恭一" ${ }^{11}$, 岡野 由典"),

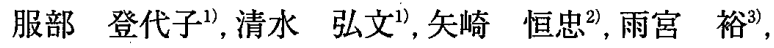
高月 健太郎 ${ }^{33}$, 石田 規雄 ${ }^{3)}$

【目的】ESWLに㧍ける腎被膜下血腫・腎周囲血腄の発生率及び要因につい て、方式の異なる 2 機種で比較检討した。対象】1998 年 2005 年の 8 年間に ESWL 治療を行った腎・上部尿管結石症例 7656 例（腎 3337 例、上部尿管 4319 例）。機種別の内訳は U/50 が 6521 例、HM-3 が 1135 例。(方法】全例治 療当日又的翌日に超音波検查で血腫の有無を確認した。血腫の分類は無症状 のものを軽度、症状を伴うものを中程度、 $\mathrm{Hb} か ゙ ~ 2 \mathrm{~g} / \mathrm{d}$ 以上減少したものを高 度とした。結果】U/50での血瘇発生率は 1.49\%（97/6521）で内訳は軽度 $0.83 \%$ 、中程度 $0.41 \%$ 、高度 $0.23 \%$ 。 HM-3 での血腄発生率は $0.26 \%(3 / 1135)$ で内訳标軽度 $0.09 \%$ 、中程度 $0.18 \%$ 、高度は $0 \%$ 。部位別発生率は腎結石で $1.86 \%(62 / 3337) 、$ 上部尿管結石で 0.88\% (38/4319) であった。年度別で発 生率に差はなかった。考察】血腫は U/50 及び HM- 3 とも背臥位での照射で 発生し、腹卧位で忟発生しなかった。HM-3 は水中放電方式の第一世代の破 碎機で、衝撃波仙垂直方向加進入し焦点領域は 16x100mm である。一方、 $\mathrm{U} / 50$ は電磁唀尊方式の第三世代の破碎機で、衝撃波は 74 度方向加進入し 焦点領域は $2.5 \times 58 \mathrm{~mm}$ である。U/50で血腫発生率が高かった理由として衝 撃波の波形や焦点形状及び㽞擊波進入角度の関与が考えられた。血腫発生の 患者側の因子としては術前の高血圧と腎孟腎炎の既往の関与が示唆された。

\section{PP-364 島田市民病院 ER を経由した尿路結石症 例の検討}

\section{市立島田市民病院}

八木橋 祐亮, 河瀬 紀夫, 福澤 重樹

人口 10 万人の中核病院である市立島田市民病院の救命セ ンター（以下 ER）を受診し、尿路結石と診断された症例お よび ER で尿路結石以外の疾患と診断されたが後日尿路結 石と診断された症例合計 109 例を検討した。さまざまな科 が当直を行っている ERで、どの程度尿路結石が正確に診 断されているか、また誤診にいたった症例などを検討した。 